\title{
ISOLATION AND TOXIN GENE DETECTION OF CLOSTRIDIUM \\ (CLOSTRIDIOIDES) DIFFICILE FROM TRADITIONAL AND \\ COMMERCIAL QUAIL FARMS AND PACKED QUAIL MEAT FOR MARKET SUPPLY - SHORT COMMUNICATION
}

\author{
Amir Hossein ZAMANI ${ }^{1}$, Jamshid RAZMYAR ${ }^{2,3}$, Fabian K. BERGER ${ }^{4 *}$, \\ Gholam Ali KALIDARI ${ }^{3}$ and Abdollah JAMSHIDI ${ }^{5}$
}

\begin{abstract}
${ }^{1}$ Faculty of Veterinary Medicine, Ferdowsi University of Mashhad, Mashhad, Iran; ${ }^{2}$ Department of Avian Diseases, Faculty of Veterinary Medicine, University of Tehran, Tehran, Iran; ${ }^{3}$ Department of Clinical Sciences, Faculty of Veterinary Medicine, Ferdowsi University of Mashhad, Mashhad, Iran; ${ }^{4}$ National Reference Center for Clostridioides (Clostridium) difficile, Institute of Medical Microbiology and Hygiene, University of Saarland, Homburg/Saar, Germany; ${ }^{5}$ Department of Food Hygiene and Aquatics, School of Veterinary Medicine, Ferdowsi University of Mashhad, Mashhad, Iran
\end{abstract}

(Received 2 July 2019; accepted 29 August 2019)

Clostridium (Clostridioides) difficile is a Gram-positive anaerobic rodshaped bacterium and the main cause of nosocomial diarrhoea in humans. In recent years, the transmission of $C$. difficile from environmental reservoirs (e.g. food) to humans has become a major focus of research. The aim of this study was to investigate the prevalence and corresponding toxin genes of $C$. difficile in faecal samples and meat of quails. Thirty samples of packed quail meat in Mashhad, Iran and 500 faecal samples (pooled to $n=5$ ) were collected on quail farms in the Northeastern Khorasan region for further investigation. Of 100 pooled quail faecal samples $10 \%$ showed cultural growth of $C$. difficile. In meat samples two out of 30 specimens (7\%) showed cultural growth. In six of ten isolates from faecal samples toxin genes $(t c d B$ and $t c d A$ ) were present, while four isolates harboured no toxin genes. However, in meat isolates no toxin genes were present. Mutations in the $t c d C$ gene were not detected, indicating that 'hypervirulent' strains such as RT027 and RT078 were not present. The data suggest that quail and quail products might hold a potential for the spread of $C$. difficile.

Key words: Clostridium difficile, prevalence, epidemiology, zoonosis, quail, poultry

Clostridium (Clostridioides) difficile is a spore-forming, anaerobic, Grampositive anaerobic rod-shaped bacterium, which has been identified as a bacterial pathogen in both humans and animals (Lawson et al., 2016). It has been impli-

"Corresponding author; E-mail: fabian.berger@uks.eu 
cated as the cause of enteric disease in a broad variety of animal species including foals, piglets, adult horses and rabbits (Levett, 1986).

In addition, some studies have raised the importance of wild animals as a reservoir of $C$. difficile for humans and domestic animals (Borriello et al., 1983; al Saif and Brazier, 1996; Baverud, 2002; Lefebvre et al., 2006; Songer and Anderson, 2006).

Antibiotic treatment seems to be the main factor of disease development since $C$. difficile can thrive when the normal gut flora is disrupted (Rupnik et al., 2009). The main virulence factors of the pathogen are toxins A and B (corresponding genes: $t c d A$ and $t c d B$ ) (Gerding et al., 2014). Some strains might additionally express a third toxin termed binary toxin (CDT) which is preferentially detected in epidemic isolates (Gerding et al., 2014). Clostridium difficile infection can be diagnosed by a variety of assays including toxigenic culture, toxin detection and toxin gene PCR (Crobach et al., 2016). Transcription of $t c d A$ and $t c d B$, being located on the pathogenicity locus (PaLoc), is controlled by two regulators, TcdR (gene: $t c d R$ ) and TcdC (gene: $t c d C$ ). TcdR is an alternative sigma factor that positively regulates transcription of $t c d A$ and $t c d B$ (Belanger et al., 2003), while TcdC negatively regulates TcdR (Dupuy et al., 2008). Of note, several studies have reported that $t c d C$ does not influence toxin production (Curry et al., 2007; Stare et al., 2007; Samie et al., 2008). However, $t c d C$ mutations in presumably 'hypervirulent' strains such as ribotype 027 (RT027) and RT078 are typical findings (Wolff et al., 2009; Persson et al., 2011). The latter genotype is furthermore detected in animals probably holding a zoonotic potential (Knetsch et al., 2014).

Concerning studies targeting poultry, the main research focus was on the prevalence in chickens, ostriches and turkeys, while data are scarce for smaller bird species such as quails (Songer, 2004; Abdel-Glil et al., 2018).

In order to assess the impact of $C$. difficile in this poultry subgroup, small traditional and larger commercial quail farms and packed quail meat were investigated for the presence of $C$. difficile. The primary aim of this study was to determine the prevalence of $C$. difficile in quails and quail meat, including further characterisation using toxin gene detection and sequencing of mutations indicative of 'hypervirulent' strains (RT027 and RT078, respectively).

One hundred pooled quail faecal samples (500 individual samples) were obtained randomly from 10 quail farms (four traditional and six commercial farms). Twenty and 80 pooled samples stemmed from traditional and commercial farms, respectively. In addition, 30 packs of quail meat (each pack consisting of five carcasses) were purchased from six different shopping centres in Mashhad, Iran. All samples originated from the Khorasan region of Iran consisting of the provinces North, South and Razavi Khorasan (population $>6$ million) and were obtained between December 2013 and April 2014. 
Ten $g$ of each homogenised faecal sample was incubated for $30 \mathrm{~min}$ at room temperature with an equal volume of $96 \%$ ethanol stock. Culturing was carried out under anaerobic conditions on Columbia agar (Merck, Darmstadt, Germany) for $72 \mathrm{~h}$. The $C$. difficile isolates were identified based on the characteristic traits including colony morphology, positive Gram staining appearance with typical spore formation and characteristic odour, and by the use of molecular confirmation by species-specific PCR (16S rRNA).

Multiplex PCR was performed to detect the toxin genes $t c d A, t c d B, c d t A B$ and $C$. difficile $16 \mathrm{~S}$ ribosomal DNA as described previously (Persson et al., 2008). Briefly, genomic DNA was extracted from a single colony using an extraction kit (Bioneer, Daejeon, South Korea) according to the manufacturer's instructions. The multiplex PCR was carried out for the detection of target genes. Amplification reactions were prepared in a $50-\mu 1$ reaction volume containing $25 \mu \mathrm{l}$ Master Mix and $25 \mu \mathrm{l}$ including primer mixture (Persson et al., 2008), template and double-distilled water. Amplification was programmed in a thermocycler (Techne TC 3000, Staffordshire, Great Britain) as follows: $94{ }^{\circ} \mathrm{C}$ for $10 \mathrm{~min}$ followed by 35 cycles of $94{ }^{\circ} \mathrm{C}$ for $50 \mathrm{sec}, 54{ }^{\circ} \mathrm{C}$ for $40 \mathrm{sec}, 72{ }^{\circ} \mathrm{C}$ for $50 \mathrm{sec}$ and a final extension at $72{ }^{\circ} \mathrm{C}$ for $3 \mathrm{~min}$.

Furthermore, $t c d C$ was analysed as described previously (Antikainen et al., 2009). Briefly, amplification reactions were prepared in a $25-\mu 1$ reaction volume containing $12.5 \mu \mathrm{l}$ MasterMix, $5 \mu \mathrm{l}$ template DNA, $1 \mu \mathrm{l}(10 \mathrm{pm} / \mu \mathrm{l})$ from each of forward and reverse primers and $5.5 \mu$ d deionised water. PCR was initiated with a denaturation step at $94{ }^{\circ} \mathrm{C}$ for $5 \mathrm{~min}$ followed by 36 cycles at $98^{\circ} \mathrm{C}$ for $10 \mathrm{sec}, 60^{\circ} \mathrm{C}$ for $20 \mathrm{sec}, 72{ }^{\circ} \mathrm{C}$ for $20 \mathrm{sec}$ and a final extension at $72{ }^{\circ} \mathrm{C}$ for $10 \mathrm{~min}$. The amplified products were detected on ethidium-bromide-stained $1.5 \%$ agarose gel (Cinnagen, Tehran, Iran) after electrophoresis and ultraviolet illumination. PCR reagents were provided by Ampliqon (Odense, Denmark) except for the DNA molecular weight marker $100 \mathrm{bp}$ originating from Dena Zist Asia (Mashhad, Iran).

Of the 100 pooled quail samples $10 \%$ showed cultural growth of $C$. difficile as confirmed by morphological traits and PCR. Samples from traditional and commercial quail farms were positive in 5/20 (25\%) and 5/80 (6\%) of the cases, respectively. In six out of ten faecal isolates, both toxin genes $(t c d B$ and $t c d A$ respectively) could be identified, while in the remaining four strains no toxin genes could be detected. In commercial farms, two toxigenic and three nontoxigenic isolates were present while in traditional farms four toxigenic and one non-toxigenic isolates were detected.

In meat samples, the prevalence of $C$. difficile was similar (7\%, 2/30). In the two meat isolates, however, no toxin genes were found. None of the isolates in either sample set showed mutations in the $t c d C$ gene indicating that 'hypervirulent' strains, in particular RT027 and RT078, were absent, which was in line with the lack of $c d t A B$ in all strains. 
Carrier rates in birds may vary greatly, ranging from 0 to $62 \%$ (Abdel-Glil et al., 2018). In poultry products such as meat $C$. difficile could be isolated from up to $15 \%$ of samples in the past, posing a potential risk for humans (Varshney et al., 2014). Several RTs being frequently encountered in human disease could be isolated in poultry in recent studies. This includes RT001 (Indra et al., 2009; Abdel-Glil et al., 2018), RT002 (Hussain et al., 2016), RT014 (Hussain et al., 2016), RT027 (Varshney et al., 2014), RT039 (Abdel-Glil et al., 2018) and RT078 (Weese et al., 2010; Varshney et al., 2014).

It is of note that RT001 (Azimirad et al., 2017; Kouhsari et al., 2019), RT014/020 [both RTs correspond to sequence type 2 in the respective study (Shoaei et al., 2019)], RT039 (Kouhsari et al., 2019) and RT078 (Jalali et al., 2012) have been detected in the Iranian population. However, most studies focused predominantly on chicken, ostriches and turkeys, and data for other poultry species such as quails are scarce. Breeding of quails for meat and egg production is of special agricultural interest in many countries besides Iran (Nasar et al., 2016; Saka et al., 2018). This emphasises the importance of a proper risk assessment concerning $C$. difficile.

The carrier rate of toxigenic $C$. difficile in faecal specimens was $6 \%$, while in meat products only non-toxigenic strains could be detected. Furthermore, no isolates with $t c d C$ mutations indicative of 'hypervirulent' strains could be found. Of note, non-toxigenic strains made up $50 \%$ of all $C$. difficile isolates. Due to the isolation of toxigenic $C$. difficile strains in quail faeces, this bird species might also hold a potential for $C$. difficile transmission. However, in quail meat no toxigenic isolates could be detected. Concerning the fact that 'hypervirulent' strains were absent, it should be taken into account that this finding is in line with most studies targeting humans in Iran except for RT078 in one study (Jalali et al., 2012) as they seem to be of minor importance in Iran (Azimirad et al., 2017; Kouhsari et al., 2019; Shoaei et al., 2019).

For a better assessment of the role of this pathogen in disease development in quails, clinical studies in these birds are needed in the future. The main limitation of this study is the non-availability of further processing to acquire further molecular data (e.g. through ribotyping). These data are, however, necessary for the comparison of the acquired isolates to globally circulating strains and to those which cause disease in the Iranian human population.

In conclusion, quails may serve as a reservoir for zoonotic $C$. difficile transmission.

\section{Acknowledgements}

The authors would like to thank Mr Ali Kargar for his technical assistance and the Research Council of Ferdowsi University, Mashhad for funding the project (grant number 29079). 


\section{References}

Abdel-Glil, M. Y., Thomas, P., Schmoock, G., Abou-El-Azm, K., Wieler, L. H., Neubauer, H. and Seyboldt, C. (2018): Presence of Clostridium difficile in poultry and poultry meat in Egypt. Anaerobe 51, 21-25.

al Saif, N. and Brazier, J. S. (1996): The distribution of Clostridium difficile in the environment of South Wales. J. Med. Microbiol. 45, 133-137.

Antikainen, J., Pasanen, T., Mero, S., Tarkka, E., Kirveskari, J., Kotila, S., Mentula, S., Kononen, E., Virolainen-Julkunen, A. R., Vaara, M. and Tissari, P. (2009): Detection of virulence genes of Clostridium difficile by multiplex PCR. APMIS 117, 607-613.

Azimirad, M., Krutova, M., Nyc, O., Hasani, Z., Afrisham, L., Alebouyeh, M. and Zali, M. R. (2017): Molecular typing of Clostridium difficile isolates cultured from patient stool samples and gastroenterological medical devices in a single Iranian hospital. Anaerobe 47, $125-128$.

Baverud, V. (2002): Clostridium difficile infections in animals with special reference to the horse. A review. Vet. Q. 24, 203-219.

Belanger, S. D., Boissinot, M., Clairoux, N., Picard, F. J. and Bergeron, M. G. (2003): Rapid detection of Clostridium difficile in feces by real-time PCR. J. Clin. Microbiol. 41, 730-734.

Borriello, S. P., Honour, P., Turner, T. and Barclay, F. (1983): Household pets as a potential reservoir for Clostridium difficile infection. J. Clin. Pathol. 36, 84-87.

Crobach, M. J., Planche, T., Eckert, C., Barbut, F., Terveer, E. M., Dekkers, O. M., Wilcox, M. H. and Kuijper, E. J. (2016): European Society of Clinical Microbiology and Infectious Diseases: update of the diagnostic guidance document for Clostridium difficile infection. Clin. Microbiol. Infect. 22, Suppl. 4, S63-81.

Curry, S. R., Marsh, J. W., Muto, C. A., O’Leary, M. M., Pasculle, A. W. and Harrison, L. H. (2007): $t c d C$ genotypes associated with severe TcdC truncation in an epidemic clone and other strains of Clostridium difficile. J. Clin. Microbiol. 45, 215-221.

Dupuy, B., Govind, R., Antunes, A. and Matamouros, S. (2008): Clostridium difficile toxin synthesis is negatively regulated by TcdC. J. Med. Microbiol. 57, 685-689.

Gerding, D. N., Johnson, S., Rupnik, M. and Aktories, K. (2014): Clostridium difficile binary toxin CDT: mechanism, epidemiology, and potential clinical importance. Gut Microbes 5, 15-27.

Hussain, I., Borah, P., Sharma, R. K., Rajkhowa, S., Rupnik, M., Saikia, D. P., Hasin, D., Hussain, I., Deka, N. K., Barkalita, L. M., Nishikawa, Y. and Ramamurthy, T. (2016): Molecular characteristics of Clostridium difficile isolates from human and animals in the North Eastern region of India. Mol. Cell. Probes 30, 306-311.

Indra, A., Lassnig, H., Baliko, N., Much, P., Fiedler, A., Huhulescu, S. and Allerberger, F. (2009): Clostridium difficile: a new zoonotic agent? Wien. Klin. Wochenschr. 121, 91-95.

Jalali, M., Khorvash, F., Warriner, K. and Weese, J. S. (2012): Clostridium difficile infection in an Iranian hospital. BMC Res. Notes 5, 159.

Knetsch, C. W., Connor, T. R., Mutreja, A., van Dorp, S. M., Sanders, I. M., Browne, H. P., Harris, D., Lipman, L., Keessen, E. C., Corver, J., Kuijper, E. J. and Lawley, T. D. (2014):. Whole genome sequencing reveals potential spread of Clostridium difficile between humans and farm animals in the Netherlands, 2002 to 2011. Euro Surveill. 19, 20954.

Kouhsari, E., Douraghi, M., Fakhre Yaseri, H., Talebi, M., Ahmadi, A., Sholeh, M. and Amirmozafari, N. (2019): Molecular typing of Clostridioides difficile isolates from clinical and non-clinical samples in Iran. APMIS 127, 222-227.

Lawson, P. A., Citron, D. M., Tyrrell, K. L. and Finegold, S. M. (2016): Reclassification of Clostridium difficile as Clostridioides difficile (Hall and O'Toole 1935) Prevot 1938. Anaerobe 40, 95-99.

Lefebvre, S. L., Arroyo, L. G. and Weese, J. S. (2006): Epidemic Clostridium difficile strain in hospital visitation dog. Emerg. Infect. Dis. 12, 1036-1037. 
Levett, P. N. (1986): Clostridium difficile in habitats other than the human gastro-intestinal tract. J. Infect. 12, 253-263.

Nasar, A., Rahman, A., Hoque, N., Kumar Talukder, A. and Das, Z. C. (2016): A survey of Japanese quail (Coturnix coturnix japonica) farming in selected areas of Bangladesh. Vet. World 9, 940-947.

Persson, S., Jensen, J. N. and Olsen, K. E. (2011): Multiplex PCR method for detection of Clostridium difficile $t c d A, t c d B, c d t A$, and $c d t B$ and internal in-frame deletion of $t c d C$. J. Clin. Microbiol. 49, 4299-4300.

Persson, S., Torpdahl, M. and Olsen, K. E. (2008): New multiplex PCR method for the detection of Clostridium difficile toxin $\mathrm{A}(t c d A)$ and toxin $\mathrm{B}(t c d B)$ and the binary toxin $(c d t A / c d t B)$ genes applied to a Danish strain collection. Clin. Microbiol. Infect. 14, 1057-1064.

Rupnik, M., Wilcox, M. H. and Gerding, D. N. (2009): Clostridium difficile infection: new developments in epidemiology and pathogenesis. Nat. Rev. Microbiol. 7, 526-536.

Saka, J. O., Oyegbami, A., Okere, I. A., Omole, A. J. and Fayenuwo, J. O. (2018): Production systems of Japanese quail (Coturnix coturnix japonica) in the urban communities of southwestern Nigeria. Trop. Anim. Health Prod. 50, 1295-1303.

Samie, A., Obi, C. L., Franasiak, J., Archbald-Pannone, L., Bessong, P. O., Alcantara-Warren, C. and Guerrant, R. L. (2008): PCR detection of Clostridium difficile triose phosphate isomerase $(t p i)$, toxin $\mathrm{A}(t c d A)$, toxin $\mathrm{B}(t c d B)$, binary toxin $(c d t A, c d t B)$, and $t c d C$ genes in Vhembe District, South Africa. Am. J. Trop. Med. Hyg. 78, 577-585.

Shoaei, P., Shojaei, H., Khorvash, F., Hosseini, S. M., Ataei, B., Tavakoli, H., Jalali, M. and Weese, J. S. (2019): Molecular epidemiology of Clostridium difficile infection in Iranian hospitals. Antimicrob. Resist. Infect. Control 8, 12.

Songer, J. G. (2004): The emergence of Clostridium difficile as a pathogen of food animals. Anim. Health Res. Rev. 5, 321-326.

Songer, J. G. and Anderson, M. A. (2006): Clostridium difficile: an important pathogen of food animals. Anaerobe 12, 1-4.

Stare, B. G., Delmee, M. and Rupnik, M. (2007): Variant forms of the binary toxin CDT locus and tcdC gene in Clostridium difficile strains. J. Med. Microbiol. 56, 329-335.

Varshney, J. B., Very, K. J., Williams, J. L., Hegarty, J. P., Stewart, D. B., Lumadue, J., Venkitanarayanan, K. and Jayarao, B. M. (2014): Characterization of Clostridium difficile isolates from human fecal samples and retail meat from Pennsylvania. Foodborne Pathog. Dis. 11, 822-829.

Weese, J. S., Reid-Smith, R. J., Avery, B. P. and Rousseau, J. (2010): Detection and characterization of Clostridium difficile in retail chicken. Lett. Appl. Microbiol. 50, 362-365.

Wolff, D., Bruning, T. and Gerritzen, A. (2009): Rapid detection of the Clostridium difficile ribotype $027 t c d C$ gene frame shift mutation at position 117 by real-time PCR and melt curve analysis. Eur. J. Clin. Microbiol. Infect. Dis. 28, 959-962. 